\title{
BMG Global Heath The Internet of Things to come: digital technologies and the End TB Strategy
}

\author{
Dennis Falzon, Mario Raviglione
}

To cite: Falzon D, Raviglione M. The Internet of Things to come: digital technologies and the End TB Strategy. BMJ Global Health 2016:1:e000038. doi:10.1136/bmjgh-2016000038

Received 8 February 2016 Accepted 17 May 2016

\section{CrossMark}

Global TB Programme, World Health Organization, Geneva, Switzerland

\section{Correspondence to}

Dr Dennis Falzon;

falzond@who.int
In his prescient novel of 1933-The Shape of Things to Come - the English writer H.G. Wells described the years from 1978 to 2059 as a time of profound social change, reinforced structures of global control and close scrutiny of human activity, as efforts united towards the creation of a utopian World State. ${ }^{1}$ From a global health perspective, the past four decades have clearly left an indelible mark. The Alma Ata declaration of 1978 heralded a worldwide shift in decentralisation of healthcare and empowerment of communities. ${ }^{2}$ The international mobilisation to address major epidemics like AIDS, vector-borne diseases and tuberculosis bore dividends. And, digital technology has facilitated epidemiological studies, research and effective advocacy through culturally appropriate social marketing techniques. Building on such successes in the face of future challenges and opportunities will require continued concerted action if public health concerns such as tuberculosis are to be consigned to history.

In 2014, the World Health Assembly resolved to end the tuberculosis epidemic in the 20 years following $2015 .{ }^{3}$ The implementation of this 'End TB Strategy' will require new approaches to prevent and treat the disease, including broad-scale action on poverty and determinants of tuberculosis, aligned fully with the United Nations' Sustainable Development Goals (SDGs). ${ }^{4}$ This implies a change in the values that governed anti-tuberculosis (TB) interventions until 2015. The 'all-of-government' approach to public health has to devolve to a larger 'all-of-society' base. The primacy of cost in priority-setting, imposed by successive years of financial adversity, needs to yield to more holistic precepts. These include the moral and solidarity principles posed by a largely curable disease which is often fatal, and the negative impact of wasted resources and polluting activities on the environment, key considerations underpinning the SDGs.

These changes will require 'disruptive' thinking to make the leap from wish to reality. How well we can leverage digital technologies and mould them to our needs could determine whether we will reach such goals or not. There is little new about employing information and communication technology (ICT) in the fight against tuberculosis: WHO has been supporting the use of ICT in surveillance, patient care, programme management, advocacy and eLearning for some time. ${ }^{5}$ Electronic databases to manage patient records are being widely deployed in low-resource settings; ${ }^{6}$ educational material for lay persons and professionals is available on many internet sites; and patients and caregivers increasingly maintain contact via text and voice over the ubiquitous mobile phone as telephone and internet coverage expand globally. Very often, however, these endeavours fail to take advantage of the full potential of existing technology and the benefits of large-scale implementation: ${ }^{7}$ when measured against what the most basic forms of online banking and airline ticket booking services offer in terms of efficiency, consistency and completeness, their performance pales miserably. Such weaknesses will persist until decision-makers and entrepreneurs become convinced of the opportunities missed when access to good-quality data is patchy or absent. Frequently, what restrains access are defects in the supporting structures which would long have been fixed had a profit motive been more evident! Sound investment cases are needed to get open standards for health data coding and exchange more broadly applied, and to have information systems created to interoperate from the moment of their inception across a broad range of health conditions and interrelated sectors-laboratory, pharmacy, imaging, genomics and clinics.

The digital health landscape is poised to be transformed, opening unprecedented opportunities for public health action (table 1). Just as remote sensing today allows security cameras, heating systems and refrigerators to communicate with household owners, sensors embedded in 'wearables' or within ingested 'smart pills' could provide an intimate level of 
Table 1 Digital health and the End TB Strategy: a history of the future?

\begin{tabular}{|c|c|c|}
\hline \multirow[b]{2}{*}{ Domains* } & \multicolumn{2}{|l|}{ Examples from... } \\
\hline & Today & Tomorrow \\
\hline \multirow[t]{5}{*}{$\begin{array}{l}\text { Integrated, patient-centred } \\
\text { care and prevention }\end{array}$} & Video-observed therapy & $\begin{array}{l}\text { Edible microchips transmitting to mobile electronic } \\
\text { devices; registering the gesture of a specific patient taking } \\
\text { a given pill }\end{array}$ \\
\hline & $\begin{array}{l}\text { Databasing laboratory results and } \\
\text { patient parameters }\end{array}$ & $\begin{array}{l}\text { Connected diagnostics } \\
\text { Tracking disease biomarkers via 'wearables' }\end{array}$ \\
\hline & Point of care testing & $\begin{array}{l}\text { Digitisation of biological material (genome, chemistry), } \\
\text { integration of data from multiple sources and remote } \\
\text { consultation of experts }\end{array}$ \\
\hline & Standardising anti-TB medication & Intimate monitoring of biomarkers to optimise care \\
\hline & $\begin{array}{l}\text { Internet-based reference and } \\
\text { eLearning content }\end{array}$ & $\begin{array}{l}\text { Decision aids informed by Big Data; advanced machine } \\
\text { learning techniques } \\
\text { Alerting people of exposure risks from real-time analysis } \\
\text { of environmental and other data }\end{array}$ \\
\hline \multirow[t]{4}{*}{$\begin{array}{l}\text { Bold policies and supportive } \\
\text { systems }\end{array}$} & $\begin{array}{l}\text { Data management shifts from paper } \\
\text { to electronic systems }\end{array}$ & $\begin{array}{l}\text { Seamless interoperability of computer networks and } \\
\text { cloud-based data sets }\end{array}$ \\
\hline & $\begin{array}{l}\text { GIS mapping of patients and } \\
\text { service providers }\end{array}$ & $\begin{array}{l}\text { Real-time localisation of individuals } \\
\text { Unique identifiers which incorporate biomarker data }\end{array}$ \\
\hline & $\begin{array}{l}\text { Conditional cash transfers as an } \\
\text { extension of micro-financing }\end{array}$ & $\begin{array}{l}\text { Rewarding behaviour linked to therapeutic effect } \\
\text { Personal genome data as a patient asset }\end{array}$ \\
\hline & $\begin{array}{l}\text { Strengthening logistic information } \\
\text { systems }\end{array}$ & Real-time tracking of equipment and consumables \\
\hline $\begin{array}{l}\text { Intensified research and } \\
\text { innovation }\end{array}$ & $\begin{array}{l}\text { Digitising data from studies } \\
\text { eLearning to build capacity in } \\
\text { conducting and translating research }\end{array}$ & $\begin{array}{l}\text { Mining data sets } \\
\text { In silico modelling of interventions using new drugs and } \\
\text { vaccines }\end{array}$ \\
\hline
\end{tabular}

${ }^{*}$ Corresponding to the three pillars of the WHO End TB Strategy. ${ }^{3}$

TB, tuberculosis.

biological monitoring - such as blood levels of medication and biomarkers of disease activity-which can maximise therapeutic effectiveness. This Internet of Things (IOT) is touted to become a game changer in the field of diagnostics, personalised care and public health. ${ }^{8}$ For it to materialise, it would require an expanded capacity to interpret live data in the light of the variety and the massive volumes by which historical records are being generated by processes in healthcare, retail, finance, leisure and the social media networks with which individuals interact. There is a growing appreciation of how 'Big Data' could contribute to operational intelligence, helping users make better-informed decisions, ${ }^{9}$ eliminate the language barrier in communication, reward healthier behaviour and cut down on waste, unnecessary travel and inconvenience. Moreover, hardware like digital spirometers and nano-biosensors linked to smartphones can allow specialist opinion to reach all levels of clinical practice, bridging 'the disintegrative influence of geographical separation' described by H.G. Wells.

These technological advances will give new meaning to personalised medicine, be it for the itinerant individual as for patients with limited mobility. ICT is also breaking new ground on other fronts important for patient-centred care, such as equity, human rights and patient empowerment. For instance, unique biometric identifiers have been assigned to over 900 million individuals in record time in India showing how digital technology can bridge inequalities and help the masses accede to their entitlements. ${ }^{10}$ Legitimate concerns about privacy and civil liberties-particularly as computing moves from hard discs to the cloud-have more recently become tempered by the viewpoint that people could profit directly from the asset value of their personal data. ${ }^{11}$ New mechanisms would need to be created to ensure that this can happen safely.

Leading minds in science and technology are voicing caution about the prospect of artificial intelligence being allowed to take the driving seat of processes hitherto controlled by humans. ${ }^{12}$ This may sound surreal for some, but the risk of losing sight of patients when medicine becomes too high tech is already conceivable to many practitioners. The national eHealth strategies that countries are implementing could broaden the discourse of how health priorities can match appropriate digital technologies while avoiding such traps. ${ }^{13}$

Anti-TB efforts are advantageously positioned to integrate new digital health methods. Such experience 
could benefit other health and social issues. Tuberculosis is firmly rooted within topical agendas as disparate as antimicrobial resistance, lifestyle risks and social determinants. It remains a concern for rich and poor countries alike. There is an entrepreneurial worldwide network of country-based public and private actors, technical agencies and donors which has shown vigorous leadership in adopting creative solutions for tuberculosis prevention and care. Proof of this is the pace and scale with which novel diagnostics and medicines are being rolled out in several countries. ${ }^{14}$ Moreover, a mature culture of patient-based monitoring within national tuberculosis programmes provides a structured framework on which innovative interventions in surveillance and care could be grafted and evaluated for effectiveness and barriers. Bold investments in digital health products could revolutionise tuberculosis prevention and care as the disease and the technology evolve within the fabric of the global interconnectedness that Wells predicted for our future.

Disclaimer The authors are staff members of the WHO. The authors alone are responsible for the views expressed in this publication, and they do not necessarily represent the decisions or policies of WHO.

Competing interests The US Agency for International Development (USAID) was a principal salary supporter of the WHO staff involved in this article but did not provide specific funding for the writing of this article. The Global TB Programme of WHO has since 2014 been supported by the European Respiratory Society to promote digital health interventions for TB care and prevention. The authors do not profit directly from this funding (eg, for salary or writing of the manuscript). They declare no other support from any organisation for the submitted work, no financial relationships with any organisations that might have an interest in the submitted work in the previous 3 years and no other relationships or activities that could appear to have influenced the submitted work.

Provenance and peer review Not commissioned; externally peer reviewed.

Data sharing statement No additional data are available.
Open Access This is an Open Access article distributed in accordance with the Creative Commons Attribution Non Commercial (CC BY-NC 4.0) license, which permits others to distribute, remix, adapt, build upon this work noncommercially, and license their derivative works on different terms, provided the original work is properly cited and the use is non-commercial. See: http:// creativecommons.org/licenses/by-nc/4.0/

\section{REFERENCES}

1. Wells HG. The shape of things to come. 1st edn. London, UK: Hutchinson \& Co., 1933.

2. Declaration of Alma Ata. International conference on primary health care, Alma-Ata, USSR, 6-12 September 1978. Geneva: World Health Organization, 1978. http://www.who.int/hpr/NPH/docs/ declaration almaata.pdf

3. Uplekar M, Weil D, Lonnroth K, et al. WHO's new end TB strategy. Lancet 2015;385:1799-801.

4. United Nations Department of Economic and Social Affairs. Sustainable development goals. New York, USA, 2015 (cited 8 July 2015). https://sustainabledevelopment.un.org/topics

5. WHO/ERS. Digital health for the End TB Strategy: an agenda for action. (WHO/HTM/TB/2015.21). Geneva: World Health Organization, 2015. http://www.who.int/tb/publications/digitalhealth-TB-agenda/en/

6. Huang F, Cheng S, Du X, et al. Electronic recording and reporting system for tuberculosis in China: experience and opportunities. J Am Med Inform Assoc 2014;21:938-41.

7. World Development Report 2016: Digital Dividends (cited 1 February 2016). http://www.worldbank.org/en/publication/wdr2016

8. The Internet of Things I McKinsey \& Company (cited 14 October 2015). http://www.mckinsey.com/insights/high_tech_telecoms_ internet/the internet of things

9. Oluoch T, Katana A, Kwaro D, et al. Effect of a clinical decision support system on early action on immunological treatment failure in patients with HIV in Kenya: a cluster randomised controlled trial. Lancet HIV 2016;3:e76-84.

10. UIDAI-Official Website (cited 12 October 2015). https://uidai.gov.in/

11. World Economic Forum. Personal Data: The Emergence of a New Asset Class (cited 9 October 2015). http://www.weforum.org/reports/ personal-data-emergence-new-asset-class

12. Why Stephen Hawking and Bill Gates Are Terrified of Artificial Intelligence I James Barrat (cited 12 October 2015). http://www. huffingtonpost.com/james-barrat/hawking-gates-artificial-intelligence b_7008706.html

13. Scott RE, Mars M. Principles and framework for eHealth strategy development. J Med Internet Res 2013;15:e155.

14. Global tuberculosis report 2015 (WHO/HTM/TB/2015.22). Geneva: World Health Organization, 2015. http://apps.who.int/iris/bitstream/ 10665/191102/1/9789241565059_eng.pdf 